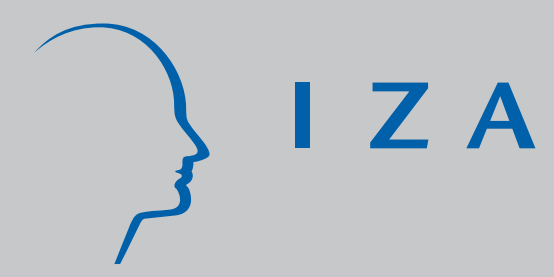

IZA DP No. 2610

Minimum Wages, the Earned Income Tax Credit, and Employment:

Evidence from the Post-Welfare Reform Era

David Neumark

William Wascher

February 2007 


\title{
Minimum Wages, the Earned Income Tax Credit, and Employment: Evidence from the Post-Welfare Reform Era
}

\author{
David Neumark \\ University of California, Irvine, \\ NBER and IZA \\ William Wascher \\ Federal Reserve Board
}

\author{
Discussion Paper No. 2610 \\ February 2007
}

\author{
IZA \\ P.O. Box 7240 \\ 53072 Bonn \\ Germany \\ Phone: +49-228-3894-0 \\ Fax: +49-228-3894-180 \\ E-mail: iza@iza.org
}

\begin{abstract}
Any opinions expressed here are those of the author(s) and not those of the institute. Research disseminated by IZA may include views on policy, but the institute itself takes no institutional policy positions.
\end{abstract}

The Institute for the Study of Labor (IZA) in Bonn is a local and virtual international research center and a place of communication between science, politics and business. IZA is an independent nonprofit company supported by Deutsche Post World Net. The center is associated with the University of Bonn and offers a stimulating research environment through its research networks, research support, and visitors and doctoral programs. IZA engages in (i) original and internationally competitive research in all fields of labor economics, (ii) development of policy concepts, and (iii) dissemination of research results and concepts to the interested public.

IZA Discussion Papers often represent preliminary work and are circulated to encourage discussion. Citation of such a paper should account for its provisional character. A revised version may be available directly from the author. 


\section{ABSTRACT \\ Minimum Wages, the Earned Income Tax Credit, and Employment: Evidence from the Post-Welfare Reform Era ${ }^{*}$}

We study the effects of minimum wages and the EITC in the post-welfare reform era. For the minimum wage, the evidence points to disemployment effects that are concentrated among young minority men. For young women, there is little evidence that minimum wages reduce employment, with the exception of high school dropouts. In contrast, evidence strongly suggests that the EITC boosts employment of young women (although not teenagers). We also explore how minimum wages and the EITC interact, and the evidence reveals policy effects that vary substantially across different groups. For example, higher minimum wages appear to reduce earnings of minority men, and more so when the EITC is high. In contrast, our results indicate that the EITC boosts employment and earnings for minority women, and coupling the EITC with a higher minimum wage appears to enhance this positive effect. Thus, whether or not the policy combination of a high EITC and a high minimum wage is viewed as favorable or unfavorable depends in part on whose incomes policymakers are trying to increase.

JEL Classification: $\quad \mathrm{H} 24, \mathrm{I38}, \mathrm{J} 2$

Keywords: minimum wage, Earned Income Tax Credit, welfare reform, employment

Corresponding author:

David Neumark

Department of Economics

3151 Social Science Plaza

University of California-Irvine

Irvine, CA 92697-5100

USA

E-mail: dneumark@uci.edu

\footnotetext{
* The authors are grateful to Stephen Ciccarella for outstanding research assistance. Neumark's research on this project was supported by the Employment Policies Institute. The views expressed are the authors' alone, and do not necessarily reflect the views of the Federal Reserve Board or its staff, or of the Employment Policies Institute.
} 


\section{Introduction}

Despite the abundance of research on the costs and benefits of minimum wage laws, they remain a subject of considerable debate. At the national level, there have been frequent proposals in recent years to increase the federal minimum wage from its current level of \$5.15 per hour, which was set in 1997 . $^{1}$ Currently, 29 states and the District of Columbia have a minimum wage that exceeds the federal wage floor; moreover, state minimum wages have recently been raised above the federal level in some large states (such as Wisconsin, Florida, Illinois, and New York), whereas - with the exception of California the states with high minimum wages had previously been relatively small. ${ }^{2}$ As a result, the share of payroll employment in states with a minimum wage higher than the federal level rose from just 7 percent in late 1997 to 50 percent in 2006, In addition, living wages, which typically set a higher minimum wage for a subset of workers in an area, have spread to scores of cities, and city-wide minimum wages have recently been enacted in San Francisco and Santa Fe. ${ }^{3}$

This ongoing interest in mandated wage floors points to the continued importance of

understanding the effects of minimum wages. And, the increasing prevalence of state and local minimum wage laws and the growing share of the work force covered by these wage floors make a direct focus on their impact particularly significant currently. Because much of the policy debate over minimum wage increases concerns their potentially adverse effects on employment opportunities for low-skilled

\footnotetext{
${ }^{1}$ Most recently, the Congress is considering legislation to raise the federal minimum wage to $\$ 7.25$ per hour over three years.

${ }^{2}$ As of September 1997, when the federal minimum wage was last raised, the following states had minimum wages above the federal level: Alaska (\$5.65); Connecticut (\$5.18); Washington, DC (\$6.15); Hawaii (\$5.25); Massachusetts (\$5.25); and Oregon (\$5.50). As of January 2007, the states with minimum wages above the federal were: Alaska (\$7.15); Arizona (\$6.75); Arkansas (\$6.25); California (\$7.50); Colorado (\$6.85); Connecticut (\$7.65); Delaware (\$6.65); Washington, DC (\$7.00); Florida (\$6.67); Hawaii (\$7.25); Illinois (\$6.50); Maine (\$6.75); Maryland (\$6.15); Massachusetts (\$7.50); Michigan (\$6.95); Minnesota (\$6.15); Missouri (\$6.50); Montana (\$6.15); Nevada (\$6.15); New Jersey (\$7.15); New York (\$7.15); North Carolina (\$6.15); Ohio (\$6.85); Oregon (\$7.80); Pennsylvania (\$6.25); Rhode Island (\$7.40); Vermont (\$7.53); Washington (\$7.93); West Virginia (\$5.85); and Wisconsin (\$6.50). For current information on state minimum wages, see the Department of Labor web site http://www.dol.gov/esa/minwage/america.htm (viewed January 8, 2007).

${ }^{3}$ For an up-to-date review of living wages and research on their effects, see Adams and Neumark (2005).
} 
individuals, we focus on employment outcomes in this paper, although we also present evidence on effects on wages and earnings. ${ }^{4}$

There exists, of course, a large body of research on the employment effects of minimum wages, which we have recently reviewed (Neumark and Wascher, 2006). Much of this research used data from the 1980s and 1990s, and sometimes earlier years as well. However, the environment of the low-wage labor market has changed considerably over the past fifteen years, suggesting that the evidence from the earlier literature on minimum wages may not be directly applicable to an evaluation of recent or future increases in state and federal minimum wages. In particular, two policy changes are likely to have changed work incentives faced by the poor and near-poor and thus the types of individuals competing for low-wage jobs.

The first such policy change was the 1996 legislation that replaced the Aid to Families with Dependent Children (AFDC) program with Temporary Assistance to Needy Families (TANF). TANF made welfare funds available to states under the condition that they introduce policies designed to move recipients off of welfare by encouraging self-sufficiency. Such policies have included specific legislation requiring welfare recipients to work, as well as limits on the number of months that families can receive welfare payments. ${ }^{5}$

The second important policy development relevant to low-wage labor markets was the expansion of the Earned Income Tax Credit (EITC). This expansion occurred along two dimensions. At the federal level, the credit rate increased sharply over the 1990s, rising from 14 percent in 1990 to 40 percent (with two children) in 1996, where it has remained since. In addition, a number of states have introduced their own EITC programs, which typically provide families in the state with a percentage supplement to the federal EITC . The number of states with such an EITC rose from seven states in 1996 to 15 states and

\footnotetext{
${ }^{4}$ Neumark, et al. $(2004,2005)$ argue that the distributional consequences of minimum wage are more important from a policy perspective. The evidence in this paper speaks to the distributional effects indirectly, by focusing on employment (and earnings) effects of minimum wages and other policies for different groups. See also Burkhauser et al. (forthcoming) for a recent discussion of the distributional effects of minimum wages and comparisons with the EITC.

${ }^{5}$ For details as well as some recent analyses of welfare reform, see Blank (2002) and Keane and Fang (2004).
} 
the District of Columbia in 2005, boosting the percentage of the 16-64 year-old population residing in states supplementing the federal EITC from 14.3 percent to 29.4 percent. $^{6}$

Because of these changes, our best estimates of the effects of minimum wages in the current labor market environment arguably will come from data for the period subsequent to these policy changes, rather than from studies that are based on information predating the period of welfare reform and EITC expansion, or that include samples extending back into the 1970s. Thus, in this paper, we base our analysis on data from 1997 to 2005, subsequent to the 1996-97 increases in the federal minimum wage, the introduction of TANF, and the increase in the federal EITC.

We first focus on results from the basic empirical framework developed and used in the existing research on the employment effects of minimum wages, which leads to a relatively standard pooled timeseries cross-section data analysis. Paralleling much of the existing research, we first estimate models for teenagers and young adults (aged 16-19 and 20-24) - relatively low-skilled individuals for whom minimum wage effects are likely to be readily apparent. However, we also extend our analysis to study the effects of the minimum wage at a more disaggregated level, focusing attention on those subgroups (e.g., minorities, high-school dropouts, etc.) for whom minimum wages might be most binding or who were more likely to have been affected by the EITC or TANF.

We then extend this framework to incorporate information on the effects of welfare reform and the EITC into our analysis. We view this extension as important for three reasons. First, because changes in welfare rules or the EITC vary across states and can directly affect employment rates for the groups we study, controlling for these changes should improve our ability to isolate the direct effects of minimum wages from the effects of other labor market policies. Second, extending the standard specification to include changes in welfare rules and the EITC along with the minimum wage will highlight differences in how these policies affect various demographic or skill groups. For example, some researchers have found

\footnotetext{
${ }^{6}$ This calculation is based on the CPS data described below. The 15 states with EITC supplements in 2005 were Illinois, Indiana, Iowa, Kansas, Maine, Maryland, Massachusetts, Minnesota, New Jersey, New York, Oklahoma, Oregon, Rhode Island, Vermont, and Wisconsin, and the supplemental EITC in those states ranges from 4.92 to 35 percent of the federal credit.
} 
that the EITC increases employment of young, unskilled women (Eissa and Leibman, 1996), ${ }^{7}$ whereas much of the minimum wage literature has found disemployment effects for a range of low-skilled workers.

Third, the incorporation of welfare reform and the EITC into our analysis helps to provide evidence on potential interactions between these policies. We view the evidence on these policy interactions — in particular, as it turns out, between the minimum wage and the EITC—as the most important contribution of this paper. Some minimum wage advocates argue that a higher minimum wage is needed to offset the reduction in market wages generated by the labor supply increases induced by a more generous EITC. A more sophisticated argument is that a higher minimum wage complements the EITC. Absent disemployment effects, a higher minimum wage will amplify the anti-poverty effects of the EITC because minimum wage workers, while scattered throughout the family income distribution, are disproportionately situated in poor families. Moreover, when the minimum wage declines in real value, a family's EITC payment can fall because the income level at which the maximum credit is received is indexed to inflation; conversely, a higher minimum wage can increase the value of the EITC. ${ }^{8}$ Furthermore, as noted by Blank and Schmidt (2000), a higher minimum wage enables a family to achieve the same level of income (earnings plus EITC) at the maximum EITC credit with a smaller EITC payment. This, in turn, reduces the marginal tax rate over the phase-out range of the credit, which could reduce some labor supply disincentives.

However, these arguments do not fully consider the potential labor market responses to the two policies, nor how they might interact for particular subgroups of the population. For example, a higher minimum wage would reduce the positive employment effect of the EITC if it reduces job opportunities for women who are induced to enter the labor market because of the EITC. On the other hand, a higher minimum wage might raise the propensity for lower-skilled women to enter the labor market in response

\footnotetext{
${ }^{7}$ Recent evidence to the contrary, based on Wisconsin's higher EITC supplement for families with three children, is reported in Cancian and Levinson (2005).

${ }^{8}$ See, for example, Economic Policy Institute (2004).
} 
to the EITC, because the combined income from labor earnings and the EITC will be higher. ${ }^{9}$ For groups less likely to be eligible for the EITC, such as female teenagers and low-skilled males, a high minimum wage coupled with an EITC could represent a "double whammy," with the minimum wage reducing their employment prospects via the higher wage imposed on employers, and the EITC reducing their employment prospects via the increased supply of women entering the labor market. Thus, the effects of interactions between policies, and how these interactive effects vary across different groups, are potentially quite complex. Widespread interest in the effectiveness of these policies at the federal level, along with the increasing number of states implementing higher minimum wages, state EITCs, and welfare reforms, makes it important to gather evidence on how they interact. ${ }^{10}$, II. Data

We construct a database that combines data on wages, employment, and hours of work of individuals with state-level information on minimum wages, earned income tax credits, and welfare policies for the period 1997 to 2005. The minimum wage data are compiled from annual summaries of federal state labor legislation reported each year in the Department of Labor's Monthly Labor Review. Most state minimum wages are specified as equal to or exceeding the federal minimum wage, although there are some states with a minimum wage that is below the federal minimum, often applying to small groups of workers not covered by the federal law. Because we do not have the detailed information on who is covered by state law and because coverage of the federal minimum wage is extensive, we simply use the higher of the state or federal minimum as the effective state minimum.

\footnotetext{
${ }^{9}$ Nothing in the conventional theory implies that employment of particular subgroups will decrease in response to a higher minimum wage; conventional theory only predicts that overall labor demand for less-skilled workers will fall. In particular, individuals for whom the market wage was previously below the reservation wage can, after an increase, find the reverse and be drawn into the labor force. For example, Neumark and Wascher (1996) find that an increase in the minimum wage induces some higher-skilled teenagers to leave school and enter the labor market.

${ }^{10}$ We are not aware of any research that has examined the interactions between the minimum wage and welfare or EITC policies. However, a number of studies have focused on the effects of minimum wage changes in the postwelfare reform era (Bernstein and Schmitt, 1998 and 2000; Neumark, 2001; Chapman, 2004; Fiscal Policy Institute, 2004), although none are as comprehensive and recent as the research in this paper. These other studies are discussed in detail in Neumark and Wascher (2006).
} 
The information on state EITCs comes from a series of reports published by the Center on Budget and Policy Priorities. State EITCs specify a percentage of the federal EITC that is paid to state taxpayers via the state income tax system, as a "supplement" to the federal EITC. Our state EITC variable is this percentage. In two states, this percentage varies with the level of income and/or with the number of children. For Wisconsin, the supplement varies with number of children; we use the supplement for families with two children (14 percent). Minnesota has its own phase-out, but the average supplement is reported as 33 percent. ${ }^{11}$ Although the state credit is refundable in most states, a few states have a nonrefundable (or only partially refundable) credit and in a couple of cases the recipient has a choice; for these latter states, we use the refundable rate, on the presumption that most eligible families would prefer that rate. (A refundable EITC gives money back to the family even if there is no tax liability, whereas a non-refundable EITC only reduces any existing tax liability.) Over our sample period, the federal EITC was unchanged with a phase-in tax credit of 40 percent for families with two or more children. As a result, identification of EITC effects comes solely from the state variation in the credit.

Characterizing state welfare policy is more difficult. The Urban Institute’s Welfare Rules Database provides a detailed characterization of each state's policies (such as benefit amounts, asset tests, work requirements, length of time benefits can be received, etc.). ${ }^{12}$ This database currently ends in 2003, but we have extended the data through 2005 using information available on a state-by-state basis from other sources. A large number of possible policy variables are available. However, because this paper is not a full-blown analysis of the effects of welfare reform, we build on the findings from Keane and Fang (2004) to choose which variables to include in our specification. In particular, they find that the most important influences on the welfare participation of single mothers are time limits and work requirements.

\footnotetext{
${ }^{11}$ See http://www.stateeitc.com.

12 See http://www.urban.org/toolkit/databases/index.cfm.
} 
We therefore focus on these two variables in our analysis. ${ }^{13}$ Variation in the welfare reform variables stems from differences in policies chosen, as well as in the timing of implementation of welfare reform. ${ }^{14}$ We merge these state-level policy variables with data from CPS Outgoing Rotation Groups (ORG). The ORG files are used to construct individual-level measures of wages, employment, and hours, as well as demographic and human capital indicators (sex, race, ethnicity, education, etc.). Finally, we append to each record the state unemployment rate in each month and the proportion of the population in each demographic and skill group we study. The latter variable is exogenous (aside from migration). The unemployment rate is potentially endogenous, but by using the state-wide unemployment rate rather than a rate for groups more strongly affected by the minimum wage, we hope to capture more of an aggregate demand indicator. These state-level controls are the standard demand and supply controls used in previous minimum wage studies.

\section{Methods}

We estimate models for wages, employment, and earnings for a wide variety of demographic and skill groups, although we focus on the employment effects of minimum wages. The earnings estimates

${ }^{13}$ In our exploratory work, we looked at numerous dimensions of time limits, including their length, how long until they are first binding on at least part of the population, etc. Similarly, we examined the impact of work requirements with and without full sanctions in terms of reduced payments, etc. However, this exploration yielded little variation in effects, so here we simply report results for whether and when a state implemented time limits and whether the state imposed work requirements.

${ }^{14}$ The coding of time limits is not completely unambiguous. In general, for the period in which a state had not yet implemented its TANF policy and was still under AFDC, the time limit is coded as 0 (unless there is a lifetime limit under a waiver) because the benefits received do not count towards the federal or state TANF lifetime limit. For the period in which a state had implemented its TANF policy and had a "periodic limit," but not a more (or less) restrictive state lifetime limit, the time limit is coded as 60 (the federal lifetime limit). When a state had both a periodic limit and a lifetime limit, the time limit is coded as the lifetime limit. For example, Arizona is coded as 0 for 1996 because it had not yet implemented TANF and had a periodic limit, but did not have a lifetime limit under a waiver. It is coded as 60 (the federal lifetime limit) beginning in January 1997 because it only had a periodic limit, and not a state lifetime limit. New York is a special case. Following Keane and Fang (2004), it is coded as 0 beginning in August 1997 because, as indicated in the Urban Institute database, "Once individuals have reached the 60-month time limit, they are eligible to receive non-cash assistance through the Safety Net Assistance program beginning 8/97.” Ohio is coded as 60 because it has a lifetime limit of 60 months. The Welfare Rules Database also indicates that there is a "benefit waiting period" in Ohio such that individuals can receive benefits for 36 months, but must wait 24 months before they can receive additional benefits. Several other sources, including the website of the U.S. Department of Health and Human Services (HHS) (http://www.acf.hhs.gov/programs/ofa/TIME2.HTM, viewed May 15, 2006), indicate that for Ohio the state lifetime limit is 36 months, effective October 1997, though HHS also states that "24 months after reaching time limit, family may receive an additional 24 months of assistance if good cause exists." Virginia is coded as 60 because it has a lifetime limit of 60 months. It also has a benefit waiting period such that individuals can receive benefits for 24 months, but must wait 24 months to receive additional benefits, although this does not affect the lifetime limit. 
are unconditional rather than conditional on employment, so that the estimates reflect changes on both the extensive (employment) and intensive (hours of work if employed) margins of work, as well as changes

in wages. All specifications are estimated at the individual level, with standard errors adjusted to account for non-independence among observations within the same state and over time. ${ }^{15}$

Denoting the dependent variable generically as $Y$, the control variables as $X$, and the minimum wage as $M W$, we begin with models for wages and employment of the form

$$
Y_{i s t}=\alpha+\log \left(M W_{s t}\right) \beta+X_{i s t} \lambda+G_{s} \mu+M_{t} v+G_{s} \cdot t \cdot \pi+\varepsilon_{i s t} .
$$

The 'i,' 's,' and 't' subscripts denote individuals, states, and months, respectively. All

specifications include fixed effects by state $(G)$ and month $(M)$. The state and time effects control for overall differences across that states that might be correlated with policy differences (such as the tendency to have higher state minimums in higher wage states), and for general changes over time (such as those generated by other policy changes) that might be correlated with minimum wages. ${ }^{16}$ Finally, the model also includes state-specific time trends. Many of the results were similar with and without the statespecific trends. However, in some cases the point estimates were quite different even if statistical tests for their exclusion were not decisive, which may reflect low power; in other cases statistical tests unambiguously called for the inclusion of state-specific trends. ${ }^{17}$

\footnotetext{
${ }^{15}$ Specifically, each observation comes from a particular state, month, and year. However, we cluster the data at the state level to compute standard errors robust to heteroscedasticity and arbitrary correlations across individuals in the same state either contemporaneously or over time (Bertrand, et al., 2004).

${ }^{16}$ For the time effects, we include a unique dummy variable for every month in the sample. In all cases, omitting the time effects led to much larger negative estimates of the effects of minimum wages on employment and hours. However, the time effects were always jointly significant, and Hausman tests (based on changes in the estimated minimum wage effects) nearly always indicated that the time effects should be included (although the test statistics are not quite correct when the standard errors of the regression model deviate from the i.i.d. assumption, which is allowed for in computing robust standard errors).

${ }^{17}$ Hausman tests tended to reject the exclusion of the state-specific trends when the estimated minimum wage effects were sensitive to including the trends. In addition, the estimated coefficients of the state-specific trends were statistically significant, based on Wald tests. The need for state-specific trends is an indication that we have been unable to identify important state-specific influences on employment and wage trends with our standard specification. One possibility is that our measure of welfare reform is inadequate. In particular, although the rules governing the TANF program were set by 1998, implementation of those policies may have evolved over time. Each state is required to report annually on their success in meeting federally-specified targets, and evidence suggests that states have moved toward those targets at different speeds. Results for the key specifications are reported without state-specific trends in Appendix Tables A1 and A2. A comparison of these results with the estimates in Tables 5, 6, and 8 provides a sense of where the findings are sensitive to the inclusion of these trends; these results are discussed further below.
} 
Two comments on the minimum wage variable are in order. First, in some of our specifications, we included the minimum wage variable with a one-year lag, reflecting earlier findings indicating that the effects of minimum wages take some time to fully become apparent (Baker, et al., 1999; Neumark and Wascher, 1992; Neumark, et al., 2004). Second, earlier research on the employment effects of wage floors often used the minimum wage divided by a measure of the average wage, capturing the idea that it is the effect of the minimum wage on the relative price of unskilled labor that is most relevant for the employment of such labor. With a logarithmic specification, the log of the minimum wage and the log of the average wage can be included separately; if the coefficients are equal in absolute value and oppositesigned, then this is equivalent to including the log of the ratio. When we included the log of the minimum wage and the log of the average wage (for males aged 35-54) separately in the employment and hours equations, the null hypothesis that these two variables had coefficients equal in absolute value but opposite in sign was often rejected. Moreover, the estimated coefficient on the minimum wage was not sensitive to excluding the average wage control. Thus, we report results including only the log of the minimum wage.

In order to capture the influences of other policy changes, we augment equation (1) by adding measures of state EITCs and welfare reform. We are interested in both the estimated effects of these variables, as well as how their inclusion influences the estimated minimum wage effects. In addition, in some specifications we include variables that allow for interactions between the various labor market policies. As it turns out, the welfare reform variables have no discernible effects on the dependent variables, so we focus on minimum wage-EITC interactions. Finally, for some of these specifications we also estimate models for earnings, in order to gauge the effects of the alternative policies (and their combinations) on a measure that summarizes the combined effects of wage changes and employment or hours changes. To simplify the specification, we specify the minimum wage variable in these models as 
the average of the current and lagged (one year) minimum wage ( $A M W$ ), estimating specifications of the form: ${ }^{18}$

$$
\begin{aligned}
Y_{i s t} & \left.=\alpha+\log \left(A M W_{s t}\right) \beta+E_{\text {ITC }} \gamma+\left[\operatorname{EITC}_{s t} \cdot\left\{\log \left(A M W_{s t}\right)-\overline{\log (A M W}\right)\right\}\right] \delta \\
& +X_{i s t} \lambda+G_{s} \mu+M_{t} v+G_{s} \cdot t \cdot \pi+\varepsilon_{\text {ist }} .
\end{aligned}
$$

\section{$\underline{\text { IV. Results }}$}

\section{Descriptive Statistics}

Table 1 reports descriptive statistics at the individual and state level, including the outcomes we study and the policy variation. The table covers the period 1997-2005, and the individual-level data are for 16-24 year-olds, except where otherwise noted. The sample is about one-half female, as expected, and there are more individuals in the 20-24 year-old age group, which encompasses one additional year of age. About 15 percent of the sample is black and 15 percent is Hispanic; these two groups are not mutually exclusive, although the overlap is very small, with only 1.3 percent of those either black or Hispanic reported as both black and Hispanic. When we disaggregate by schooling level, we focus on 2024 year-olds, since their current schooling is more likely to be indicative of their completed schooling. Among 20-24 year-olds, 44.5 percent have completed at most a high school education, and 13.6 percent have not completed high school (and are labeled high school dropouts, although they of course may complete high school later). ${ }^{19}$ The average state unemployment rate faced by sample members in this period was 5 percent. Our regression models also include the proportion of the age-skill-demographic group in the population, but because there are many such proportions calculated for the different age, skill, and demographic group combinations we consider, we do not report the descriptive statistics, except for the proportions of the overall population that are in the 16-19, 20-24, and 16-24 year-old age groups; these are, respectively, .079, .093, and .172.

\footnotetext{
${ }^{18}$ Note that we demean the average minimum wage variable in the interaction. This enables us to interpret the estimated coefficient on the EITC variable as the effect of the state EITC at the average minimum wage in the sample, and has no impact on the estimated coefficient of the interaction.

19 The education classifications are based on education attained and whether the person reports a high school diploma or GED. We do not distinguish between the latter two cases, although there is evidence suggesting that this distinction is important for employment outcomes (e.g., Cameron and Heckman, 1993). Separate information on diploma and GED holders is first available in the CPS in 1998.
} 
The second panel of the table reports on the labor market outcomes we study. As expected, average wages are higher for 20-24 year-olds than for 16-19 year-olds, as are employment rates and earnings (unconditionally, which is what we study in the regression models, as well as conditional on positive earnings). ${ }^{20}$ The policy variables shown in the last panel indicate that across all observations, the minimum wage averaged $\$ 5.37$ per hour, 22 cents higher than the federal minimum wage. Of course as indicated earlier, state minimum wages and the number of states with a minimum wage above the federal level rose over the sample period. For individuals in states with a higher minimum, the average minimum wage was \$6.31 per hour, 22.5 percent above the federal minimum. On average, sample members faced state EITC supplements of 4.1 percent, with the figure four times as high for observations with state EITCs. Over 80 percent of the observations on individuals in states that supplement the EITC are from states with a refundable EITC, and in almost all cases the EITC is fully refundable.

\section{Effects of Minimum Wages on Employment}

We begin our empirical analysis of minimum wages with basic regression estimates of their effects on employment. Table 2 reports the coefficient estimates from regressions for the three age groups, for 20-24 year-olds with a high school education or less, and for 20-24 year-olds who dropped out of high school. The following two tables report results disaggregated by race and ethnicity, and then disaggregated further by sex.

The first specification includes the contemporaneous minimum wage, the control variables, and state and time fixed effects, but excludes the state-specific trends. The second specification adds in the state-specific trends. In the third specification, we substitute the lagged minimum wage for the contemporaneous minimum wage, while in the fourth we include both. We show results for all of these specifications, but the discussion tends to emphasize the summed contemporaneous and lagged effects from the fourth specification.

\footnotetext{
${ }^{20}$ All wage, earnings, and minimum wage figures are nominal. The time effects in the regression models will account for aggregate nominal changes.
} 
The estimates for all individuals combined, distinguished only by age, are reported in the first three columns of Table 2. Regardless of specification, the point estimates are consistent with the strongest negative effects for 16-19 year-olds, followed by 16-24 year-olds combined, and then 20-24 year-olds, as we would expect if the youngest individuals are the least skilled. For the two older groups none of the estimates are statistically significant, and for the 20-24 year-olds the estimates are generally slightly positive. For teenagers, we find a marginally significant negative estimate for the specification excluding state-specific trends, but not when the trends are included, although the estimates do not change by that much. In the specification that combines contemporaneous and lagged effects, the contemporaneous effect is marginally significant, but neither the lagged nor the summed effect is. For the two low schooling groups, the estimates are also insignificant, although for high school dropouts the point estimates are quite large, especially when lagged effects are included. For the last specification, which includes both contemporaneous and lagged effects, we report the implied elasticities of employment for the relevant group with respect to changes in the minimum wage. For teenagers, the estimated elasticity is -.16. This is in the typical "consensus” range of minimum wage elasticities (Brown, 1983; Fuchs, et al., 1998), although as noted above, the estimate is not statistically significant. The next three estimated elasticities are small, while for high school dropouts aged 20-24 the estimate is much larger. Nonetheless, for estimates that do not disaggregate by race, sex, or ethnicity, we fail to find statistically significant effects of minimum wages.

Table 3 reports estimates disaggregated by race and ethnicity. Estimates are reported for nonblack, non-Hispanics; for blacks and Hispanics combined; and then for the two groups separately. The differences between the results for the different race and ethnic groups are striking. Given that non-black, non-Hispanics make up a large share of the overall sample, the results for this group are very similar to those for the full sample. But for blacks and Hispanics combined, in specifications including the lagged effect there is strong and statistically significant evidence of disemployment effects of minimum wages for both the 16-19 and 16-24 age groups. For teens, the implied elasticity from the specification that includes both contemporaneous and lagged effects is -.66 , and for $16-24$ year-olds it is -.39 . When we 
estimate the model separately for blacks and for Hispanics, we find that although there are some large negative point estimates for blacks, the statistically significant evidence of negative employment effects is strongest for Hispanics, especially for 16-24 and 20-24 year-olds (with the evidence for the latter group only marginally significant). The estimated elasticity for Hispanic teens (-.43) is similar to those for the other age groups, but not significant.

In Table 4, we also disaggregate by sex. Because of small samples, we do not show separate results for blacks and for Hispanics in this table. Here, the differences in the estimated effects of minimum wages across the various demographic groups are even more striking. In particular, for most of the female groups (see the lower panel) there is virtually no evidence of a significant effect of minimum wages on employment. The one exception is for 20-24 year-old high school dropouts, for whom there is strong evidence of a lagged disemployment effect. The point estimate for minority teenagers is also large and negative (-.55), but insignificant. Other than that, the estimates are generally quite small.

The estimates for men show a sharply different pattern. For all race and ethnic groups combined, there is no significant evidence of disemployment effects once the state-specific trends are included; the same is true for non-black, non-Hispanic men. But for black or Hispanic men, the evidence strongly suggests that minimum wages reduce employment, with statistically significant negative effects for 16-24 and 20-24 year-olds (and a larger, but insignificant, implied elasticity for teenagers). For the lowschooling groups, the point estimates are negative but insignificant, and contrary to expectations, more negative for those with a high school education or less than for high school dropouts. ${ }^{21}$

To display the employment results more conveniently, the first column of Table 5 reports all of the estimated employment elasticities from Tables 2, 3, and 4. As explained in the notes to the table, we generally report the summed contemporaneous and lagged effects from specification 4, except in cases where the data indicate that the specification with only a contemporaneous or only a lagged effect is preferred.

\footnotetext{
${ }^{21}$ Burkhauser et al. (2000) also report stronger negative effects of minimum wages for minority teens and highschool dropouts, although their models exclude year fixed effects.
} 
For the post-welfare reform period, the message is quite clear. There is virtually no evidence that higher minimum wages reduced women's employment, except perhaps for the very least-skilled high school dropouts. Moreover, the estimated elasticities are often positive rather than negative, indicating that the issue is not one of negative but insignificant point estimates. In contrast, there is quite strong evidence that higher minimum wages in this period led to disemployment among young minority men. ${ }^{22}$

\section{Effects of Minimum Wages on Wages}

We also estimated similar models for log wages. These results, which refer to individuals who are employed, are summarized in the second column of Table 5. As for the employment specifications, we generally report summed contemporaneous and lagged effects, except in cases where the data indicated that the specification with only a contemporaneous or only a lagged effect is preferred. ${ }^{23}$ For the wage (and later the earnings) estimates, the dependent variable is already in logs, so the estimated coefficients (or their sums) are directly interpretable as elasticities.

When we disaggregate only by age, the estimated effect on wages is positive in all cases. It is larger for 16-19 year-olds than for 16-24 or 20-24 year-olds, and the estimate is smallest for the latter group. It is significant for 16-19 year-olds but not for the other two groups. The estimated wage effect is also positive and significant for 20-24 year-olds with less schooling, with the effect largest among high school dropouts. Taken as a whole, these estimates suggest that the size of the effect is inversely related to skill level. Note, however, that the estimated elasticities are well below one, most likely because even in these low-skill groups, many workers earn above the minimum wage.

\footnotetext{
${ }^{22}$ Appendix Table A1 reports the same set of employment elasticities from specifications that omit the state-specific trends. The results differ mainly for the smaller groups (minorities, those with less education, etc.). In general, though, there is still evidence of negative employment effects for minority men, as well as for the overall 16-19 and 20-24 year-old groups and non-black, non-Hispanics in these age groups. There is no evidence of disemployment effects for females.

${ }^{23}$ Although past work has tended to emphasize the importance of lagged effects of minimum wages on employment, they can also be relevant to wage effects. For instance, there may be some implicit "give-back" in periods subsequent to minimum wage increases when other workers receive raises but those directly affected by a recent minimum wage increase do not (see the evidence in Neumark, et al., 2004, for workers very near the minimum). Alternatively, there could be lagged positive effects, either because of a lag in compliance or because part of the response occurs as employers substitute towards higher-skilled workers, which bids up their wages. The estimates from specifications that include both contemporary and lagged effects tended to be somewhat larger than just the contemporaneous effects, but they were qualitatively similar.
} 
Disaggregating by race and ethnicity, we only find a positive and significant effect for non-black, non-Hispanic teens. For the minority groups, there are no significant effects, and for Hispanics (and black and Hispanic teens combined) the point estimates are negative. ${ }^{24}$ Disaggregating by sex as well, the overall results for the three age groups are quite similar, with positive and significant effects for teenage males and females, and smaller and insignificant effects for 16-24 year-old females and for 20-24 yearolds. The results are also similar for the non-black, non-Hispanic subsamples. For black or Hispanic females, the estimated wage effects are insignificant except for 20-24 year-olds. For minority teen males, there is statistically significant evidence of a negative effect. For the two groups of less-educated 20-24 year-olds, for men we find a stronger positive wage effect for dropouts than for the broader subgroup of those with a high school education or less, whereas for women the estimates for the two education groups are similar.

Overall, the estimates point to positive effects of minimum wages on the wages of least-skilled workers, although there is a handful of cases of negative effects, which may be explained by the underlying economics or may reflect data issues (including smaller samples).

Minimum Wages, the EITC, and Welfare Reform

Perhaps the most obvious question that arises with respect to changes in the other policy variables is whether the pattern of these changes can help to explain the apparent absence of negative effects of minimum wages on employment for females. For example, if the EITC encourages women with children to work and if states increasing minimum wages were also raising their EITCs, the disemployment effects of minimum wages might not be apparent in specifications that omit the EITC variable; the same argument applies to welfare reform.

To explore the effects of the EITC and welfare reform on women's employment, specification 1 in Table 6 adds the state EITC and indicators for time limits and work requirements adopted as part of

\footnotetext{
${ }^{24}$ Note that just as we should not necessarily expect employment declines for all groups in response to a higher minimum wage, we should not necessarily expect wage increases for all groups. A higher minimum wage could cause specific subgroups of the population to increase their employment rates, with the outward labor supply shift reducing wages of other groups (as well as their employment).
} 
welfare reform to the specification that includes contemporaneous and lagged minimum wages. The estimates are reported for the same subgroups of women included in Table 4.

One notable aspect of these results is that there is no evidence of an effect of welfare reform on women's employment. The estimates are never statistically significant, either individually or jointly. The estimated effects of time limits are either negative or centered on zero, while the estimated effects of work requirements are positive, as might be expected.

On the other hand, with the exception of teenagers (of any race or ethnic group) and high school dropouts, the evidence suggests that state EITCs have a strong positive effect on women's employment. For example, the estimate for 20-24 year-olds as a whole (.302) implies that a 10 percent EITC supplement boosts the probability of employment by three percentage points. It is not surprising that we find no effect for teenagers, since few of them have children. ${ }^{25}$ Conversely, the estimated effects are larger for minority women, who have higher fertility rates at ages $20-24{ }^{26}$

Of course it would be ideal to accurately identify who is eligible for the EITC and to determine whether the expected effects appear for the right groups (i.e., employment increases for the eligible). Eligibility can depend on whether one has children, as well as age, enrollment status, financial dependency, and of course family income. Unfortunately, with the CPS ORG files used for this analysis, identifying the eligibles along the most straightforward lines of who has children is problematic. ${ }^{27}$ Thus, there is clearly scope for further refinement and analysis of the EITC effects based on identification of

\footnotetext{
${ }^{25}$ In June 2004, only 6.7 percent of 15-19 year-olds had children; figures are not reported for 16-19 year-olds (see www.census.gov/population/www/socdemo/fertility.html, viewed September 11, 2006).

${ }^{26}$ The same source cited in the previous footnote indicates that the share of white women aged 20-24 with children was 29.2 percent, versus 43 percent for blacks and 47.2 percent for Hispanics.

${ }^{27}$ In the monthly CPS files, respondents are not asked about number of children (under 18) until 1999. Furthermore, this is only asked of householders or their spouses. This is an endogenously selected subsample in terms of family structure and income, with inclusion in it potentially related to labor market outcomes and EITC receipt.
} 
eligibility status, and it would be wise to interpret the results for the effects of the EITC cautiously until such work has been completed. ${ }^{28}$

Despite this evidence that the EITC raises employment among women, adding the EITC (and welfare reform) variable(s) to the specification has little influence on the estimated minimum wage effects. Thus, the absence of disemployment effects of minimum wages for women in this period appears to be a real result, and not attributable to the exclusion of other policy changes correlated with minimum wage increases.

We next look for evidence of policy interactions. Given the absence of any effect on employment from welfare reform, and the strong effects of the EITC, we focus on potential minimum wage-EITC interactions. As described above, to eliminate the extra complication of allowing for interactions between the EITC and both contemporaneous and lagged minimum wages, we instead use a specification that includes the average of the current and lagged minimum wage variables (the average of the logs). We first report estimates for this model (specification 2) to verify that nothing changes qualitatively. In particular, the minimum wage employment elasticities for specification 2 are very similar to those in the earlier tables. Specification 3 includes this minimum wage variable and the EITC, along with their interaction. As noted earlier, for women who are eligible for the EITC, the disemployment effects of a higher minimum wage could reduce the positive employment effect of the EITC. Alternatively, the interaction for these women could be positive, because a higher minimum wage makes the EITC more valuable for eligible families. In contrast, for groups not likely to be eligible for the EITC, such as female teenagers and males, a high minimum wage coupled with an EITC could be a particularly bad combination, with the minimum wage reducing their employment prospects via the higher wage floor

\footnotetext{
${ }^{28}$ Another issue is the refundability of the EITC, and whether this affects the strength of its impact. In general, a refundable EITC should have more impact, because it is valuable even if the family owes no income taxes, and is more valuable if the value of the credit exceeds the tax liability. Similar models were estimated including both the EITC variable and this variable interacted with the proportion of the EITC that is refundable (this value is either one or zero in almost all cases, with the only exception being Rhode Island, which has a partially refundable EITC). The models were estimated for 20-24 year-old women, and the various subgroups thereof. There was never a significantly higher effect of the EITC when it was refundable, although in almost all cases the point estimates indicated stronger effects in these cases. Given the weakness of the results, however, in the ensuing analysis we simply focus on the EITC without regard to refundability.
} 
imposed on employers, and the EITC further reducing their employment prospects via the increased supply of eligible women entering the labor market.

The evidence on employment is consistent mainly with the latter interactive effect, with a negative and statistically significant minimum wage-EITC interaction evident for both the overall teenage category and for the subgroup of minority teenagers. To help in interpreting the coefficient estimates, the bottom rows of the table report the implied minimum wage elasticity for states with no EITC, with a relatively low EITC supplement of 10 percent, and with a high EITC supplement of 25 percent. In all of the specifications for teenagers (as well as for 16-24 year-olds as a whole and the two lower schooling groups), the minimum wage elasticities become more negative with a higher EITC, reflecting the negative estimate of the interactive coefficient. Furthermore, for all teenagers and for minority teenagers, the implied minimum wage elasticity is only significant at the higher EITC supplement (marginally so for all teenagers). In addition, although the interaction coefficient itself is not statistically significant in the equation for high school dropouts, the implied elasticity in that equation is significant at both the 10 percent and the 25 percent EITC supplement levels (marginally for the 10 percent EITC). In contrast to these negative results, a higher minimum wage coupled with a high EITC (25 percent) has a significant positive effect on the employment rate of 20-24 year-old minority women.

In sum, the EITC increases employment for almost all groups of women aged 20-24. On the other hand, a high minimum wage combined with a high EITC reduces employment of female teenagers but raises employment among minority women aged 20-24. This boost to employment of 20-24 year-old minority women, even if coupled with lowered employment among female teenagers, might be viewed as a good policy outcome on distributional grounds, as the 20-24 year-old minority women are more likely to have children to whom we would like to direct some of the benefits of the EITC. Thus, although some 
groups appear to gain and others to lose by combining a higher minimum wage with a more generous EITC, the gains may accrue to groups with greater needs. ${ }^{29}$

To this point we have only examined the employment effects of the minimum wage and the EITC. These policies may also affect hours and wages. Thus, in Table 7 we report estimates from similar specifications for wages and for earnings (wages times weekly hours, with earnings defined as zero for the non-employed) to get a better sense of how these policies — and their interaction-affect the economic well-being of women. For wages, there was no evidence of minimum wage-EITC interactions, and so we simply report the specification with the minimum wage and EITC variables added separately. The most interesting result revealed by these estimates is that the EITC reduces wages for 16-24 and 20-24 year-old minority women. ${ }^{30}$ These negative wage effects work in the opposite direction from the positive employment effects shown in Table 6, indicating that the overall impact of the EITC is best assessed by looking at its effect on earnings.

For earnings, the first specification includes the minimum wage and EITC variables, while the second adds their interaction. For the first specification, the estimated effects of the minimum wage are sometimes positive and sometimes negative. The largest effect, and the only one that is significant (marginally), is for 20-24 year-old black or Hispanic women, for whom the elasticity of earnings with respect to the minimum wage is .80 . Looking back at Table 5 , we see that the wage effect for this group was one of the highest and that the employment effect was small but positive, which explains the positive earnings effect. The estimated effects of the EITC on earnings are positive across the board. Not surprisingly given the employment effects reported in Table 6, the estimated earnings effects are largest for 20-24 year-olds, although the estimates are statistically significant only for the larger 16-24 year-old groups (all, and non-black, non-Hispanic). The estimates are especially large, and also marginally

\footnotetext{
${ }^{29}$ Results for a version of this last specification that excludes the state-specific trends are reported in the top panel of Appendix Table A2. The positive effects of the EITC on employment persist for minority women and those with a high school education or less, although in this case the effect is also apparent for high school dropouts. However, the evidence of positive minimum wage-EITC interactions is weaker, but for those with a high school education or less becomes positive and significant for a high EITC.

30 These adverse effects of the EITC on wages of low-skill groups, which we also find for men below, parallel findings reported in Leigh (2004).
} 
significant, for the two low-schooling groups of 20-24 year-olds. These groups are likely to reap the most from the EITC since their earnings are low and thus less likely to be in the phase-out range where the EITC can generate incentives to work less rather than more. In addition, less-educated women are more likely to have children at these ages. Curiously, the estimated effect is also positive and marginally significant for all teenagers, although for minority teenagers the estimate is near zero. In general, it appears that the positive effects of the EITC on women's employment outweigh the negative wage effects, suggesting that the gains from the EITC are not completely dissipated by wage reductions stemming from outward labor supply shifts. ${ }^{31}$

The specifications that include the minimum wage-EITC interaction are reported in the bottom part of the table. Two findings are of note. First, groups for which the employment estimates in Table 6 indicated adverse effects of a high minimum wage coupled with a high EITC (all teenage women, minority teenagers, and 20-24 year-old high school dropouts) show a similar result for earnings. In particular, , the estimated coefficient of the interaction is negative and at least marginally significant for each of three groups, and, in the case of high school dropouts, the negative effect of a higher minimum wage is particularly strong when the state EITC is high. Second, paralleling the employment results, the effect of the minimum wage-EITC interaction is positive and significant for 20-24 year-old minority women. This result corresponds to our earlier argument that a higher minimum could enhance the positive impact of the EITC by encouraging work (even if, overall, a higher minimum reduces employment). Thus, for younger, non-teenage minority women there does appear to be a potentially beneficial impact from combining a high EITC with a higher minimum wage.

Finally, we turn to the effects of the EITC and the minimum wage on men. Focusing first on the EITC, we would not expect to see a positive effect on employment both because fewer men live with children and because men are more likely to be employed regardless of the EITC. In addition, if the EITC induces increased labor supply of women (via labor market entry), some men may face more

\footnotetext{
${ }^{31}$ The middle panel of Appendix Table A2 reports the earnings results for women from specifications that exclude the state-specific trends. The evidence of positive EITC effects is weaker statistically than in Table 7, although qualitatively similar. The same is true of the evidence on minimum wage-EITC interactions, discussed below.
} 
competition for jobs and hence lower wages (Leigh, 2004). A higher minimum wage coupled with an EITC could cut in different ways. On the one hand, a high minimum wage that leads to more labor market entry among women eligible for the EITC would put additional downward pressure on wages for men. On the other hand, a higher minimum wage could create a floor below which wages cannot fall despite the increased labor supply of women, in which case a higher minimum wage coupled with a higher EITC might reduce men’s employment.

To explore these questions, we first estimated models for men's employment incorporating the EITC and minimum wage-EITC interactions, but detected no substantive or significant employment effects of the EITC; hence, we do not report these results. However, as reported in Table 8, we do find evidence that the EITC reduces earnings for some groups of men, as well as evidence of a negative interaction between the minimum wage and the EITC on both wages and earnings. The top panel reports the wage effects. For minority men aged 16-24 and 20-24, the estimated effect of the EITC is significantly negative and the estimated interactive effect of the minimum wage and the EITC is negative and marginally significant. As before, we also report the implied minimum wage effect for different levels of the state EITC, and at high levels of the EITC, the estimated minimum wage elasticity is negative and marginally significant. For most other groups (such as all teenagers and 20-24 year-old high school dropouts), the positive effect of the minimum wage on wages is reduced or eliminated the higher is the EITC, reflecting the negative point estimates of the minimum wage-EITC interaction.

The bottom panel reports the estimates for earnings. Given the absence of strong employment effects, these generally mirror the wage effects. In particular, as shown in specification 1 , which excludes the interaction term, the EITC reduces earnings for 20-24 year-old minority men. Moreover, as shown in specification 2, the negative effect of the EITC on earnings is larger when the minimum wage is high, as indicated by the significant negative estimate of the interactive effect. The results are similar for the broader group of 16-24 year-old minority men, and a comparison of the estimated elasticities in Tables 7 and 8 suggests that the negative effects of the EITC on men's earnings are somewhat larger than the 
positive effects of the EITC on women's earnings. ${ }^{32}$ Finally, there is no evidence that a higher minimum wage increases men's earnings, whereas there is some evidence of adverse earnings effects for minority men. ${ }^{33}$

\section{$\underline{\text { V. Conclusions }}$}

The low-wage labor market has undergone substantial changes since the first wave of the "new minimum wage" research published in the early- and mid-1990s. Welfare reform and the growth of state EITCs have changed incentives to work, and in doing so have potentially changed the effects of minimum wages. Moreover, the proportion of states with a minimum wage above the federal level has increased noticeably in recent years, boosting interest in the effects of the minimum wage in smaller geographic markets. In this paper, therefore, we study the effects of minimum wages in the post-welfare reform era and compare their influences on employment and earnings with the effects of state EITCs and welfare reforms. In addition, we estimate models that allow for interactions between minimum wages and the EITC, to assess the oft-stated claim that combining a more generous EITC with a higher minimum wage may lead to more beneficial effects of the EITC and reduce some of its adverse consequences.

Our results indicate that the increases in minimum wages in recent years have had adverse effects on employment, with the effects concentrated on young minority men. For these men, we estimate statistically significant elasticities in the range of -.5 or -.6 . For young white men, the estimated effects are negative, but somewhat smaller and not statistically significant. For young women, we find essentially no evidence of an effect of minimum wages on employment, with the exception of high school dropouts. Furthermore, this absence of disemployment effects for women is not the result of estimating models that omit other policy changes that could influence employment. When we incorporate information on state EITCs and state variation in welfare reform, we continue to find little evidence that minimum wages affect employment. At the same time, there is strong evidence that the EITC boosts

\footnotetext{
${ }^{32}$ Again, Appendix Table A2 reports results for men's earnings excluding the state-specific trends. These results are much weaker, and in particular the negative effects on minority males are not apparent.

${ }^{33}$ The same is true of specifications excluding the minimum wage-EITC interaction.
} 
employment of young women (although not teenagers), but little evidence of any effects from welfare reform.

We also explore the question of how minimum wages and the EITC interact in affecting both women and men. There are possible explanations as to why a higher minimum wage could enhance the effect of the EITC for women, by inducing particular subgroups to increase their employment rates to a greater extent than would be caused by the EITC alone. But it is also possible for a high EITC coupled with a high minimum wage to have adverse effects, especially for men who may have to compete with the women induced to enter employment by a higher EITC.

We find evidence of an interaction between the EITC and the minimum wage, although the direction of this interactive effect differs across groups. In particular,. the EITC appears to boost employment and earnings for minority women, and coupling the EITC with a higher minimum wage appears to enhance this positive effect. In contrast, we find that the negative effects of minimum wages on earnings of minority men is more pronounced when the EITC is high, suggesting that the increment to women's labor supply induced by the EITC-minimum wage interaction puts downward pressure on the wages of low-skilled men. Similarly, earnings for female teenagers and 20-24 year-old high school dropouts are reduced by a combination of a high minimum wage and generous EITC. Thus, whether or not the policy combination of a high EITC and a high minimum wage is viewed as favorable or unfavorable depends on whose incomes policymakers are targeting. 


\section{References}

Abowd, John M., Francis Kramarz, Thomas Lemieux, and David N. Margolis. 2000. "Minimum Wages and Youth Employment in France and the United States.” In David G. Blanchflower and Richard B. Freeman, eds., Youth Employment and Joblessness in Advanced Countries (Chicago: The University of Chicago Press), pp. 427-72.

Adams, Scott, and David Neumark. 2005. "Living Wage Effects: New and Improved Evidence.” Economic Development Quarterly, Vol. 19, No. 1, February, pp. 80-102.

Baker, Michael, Dwayne Benjamin, and Shuchita Stanger. 1999. "The Highs and Lows of the Minimum Wage Effect: A Time-Series Cross-Section Study of the Canadian Law.” Journal of Labor Economics, Vol. 17, No. 2, April, pp. 318-50.

Bernstein, Jared and John Schmitt. 2000. "The Impact of the Minimum Wage: Policy Lifts Wages, Maintains Floor for Low-Wage Labor Market.” Economic Policy Institute, Washington, D.C.

Bernstein, Jared and John Schmitt. 1998. "Making Work Pay: The Impact of the 1996-97 Minimum Wage Increase.” Economic Policy Institute, Washington, D.C.

Bertrand, Marianne, Esther Duflo, and Sendhil Mullainathan. 2004. "How Much Should We Trust Differences-in-Differences Estimators.” Quarterly Journal of Economics, Vol. 119, No. 1, February, pp. 249-75.

Blank, Rebecca M. 2002. "Evaluating Welfare Reform in the United States.” Journal of Economic Literature, Vol. 40, No. 4, December, pp. 1105-66.

Blank, Rebecca M., and Lucie Schmidt. 2001. "Work, Wages, and Welfare.” In Rebecca M. Blank and Ron Haskins, eds., The New World of Welfare (Washington, DC: The Brookings Institution), pp. 70-102.

Brown, Charles, Curtis Gilroy, and Andrew Kohen. 1983. "The Effect of the Minimum Wage on Employment and Unemployment.” Journal of Human Resources, Vol. 18, No. 1, June, pp. 3-31.

Burkhauser, Richard V., Kenneth A. Couch, and David C. Wittenburg. 2000. "Who Minimum Wage Increases Bite: An Analysis Using Monthly Data from the SIPP and the CPS.” Southern Economic Journal. Vol. 67, No. 1, January, pp. 16-40.

Burkhauser, Richard V., and Joseph J. Sabia. "The Effectiveness of Minimum Wage Increases in Reducing Poverty: Past, Present and Future.” Forthcoming in Contemporary Economic Policy.

Cameron, Stephen, and James J. Heckman. 1993. “The Nonequivalence of High School Equivalents.” Journal of Labor Economics, Vol. 11, No. 1 (Pt. 1), January, pp. 1-47.

Cancian, Maria, and Arik Levinson. 2005. "Labor Supply Effects of the Earned Income Tax Credit: Evidence from Wisconsin’s Supplemental Benefit for Families with Three Children.” NBER Working Paper No. 11454.

Chapman, Jeff. 2004. "Employment and the Minimum Wage: Evidence from Recent State Labor Market Trends.” Economic Policy Institute, Washington, D.C.

Economic Policy Institute. 2004. "The Minimum Wage and Earned Income Tax Credit: Partners in Making Work Pay.” Available at www.epinet.org/content.cfm/webfeatures_snapshots_05052004 (viewed May 24, 2004).

Eissa, Nada, and Jeffrey Leibman. 1996. "Labor Supply Response to the Earned Income Tax Credit.” Quarterly Journal of Economics, Vol. 112, No. 2, May, pp. 605-37.

Fiscal Policy Institute. 2004. "State Minimum Wages and Employment in Small Businesses.” Fiscal Policy Institute, New York, NY.

Fuchs, Victor R., Alan B. Krueger, and James M. Poterba. 1998. "Economists' Views About Parameters, Values, and Policies: Survey Results in Labor and Public Economics.” Journal of Economic Literature, Vol. 36, No. 3, September, pp. 1387-425.

Keane, Michael P., and Hanming Fang. 2004. "Assessing the Impact of Welfare Reform on Single Mothers.” Brookings Papers on Economic Activity, 1, pp. 1-116.

Leigh, Andrew. 2004. "Who Benefits from the Earned Income Tax Credit? Incidence Among Recipients, 
Coworkers, and Firms.” Unpublished paper, Australian National University.

Neumark, David. 2001. "The Employment Effects of Minimum Wages: Evidence from a Prespecified Research Design.” Industrial Relations, Vol. 40, No. 1, January, pp. 121-44.

Neumark, David and William Wascher. 1992. "Evidence on Employment Effects of Minimum and Subminimum Wages: Panel Data on State Minimum Laws.” Industrial and Labor Relations Review, Vol. 46, No. 1, October, pp. 55-81.

Neumark, David, and William Wascher. 1996. "The Effects of Minimum Wages on Teenage Employment and Enrollment: Estimates from Matched CPS Data.” Research in Labor Economics, Vol. 15, pp. 25-64.

Neumark, David, and William Wascher. 2006. "Minimum Wages and Employment: A Review of Evidence from the New Minimum Wage Research.” National Bureau of Economic Research Working Paper No. 12663, Cambridge, MA.

Neumark, David, Mark Schweitzer, and William Wascher. 2004. "Minimum Wage Effects Throughout the Wage Distribution.” Journal of Human Resources, Vol. 39, No. 2, pp. 425-50.

Neumark, David, Mark Schweitzer, and William Wascher. 2005. "The Effects of Minimum Wages on the Distribution of Family Incomes: A Non-parametric Analysis.” Journal of Human Resources, Vol. 40, No. 4, pp. 867-917.

Sabia, Joseph J. 2006. "The Effect of Minimum Wage Increases on Retail and Small Business Employment.” Unpublished paper, University of Georgia. 
Table 1: Descriptive Statistics, 16-24 Year-Olds, 1997-2005

\begin{tabular}{|c|c|c|c|}
\hline & Mean & Standard deviation & $\mathrm{N}$ \\
\hline \multicolumn{4}{|l|}{$\begin{array}{l}\text { Individual and state } \\
\text { characteristics }\end{array}$} \\
\hline Aged 16-19 & .466 & $\ldots$ & 390,617 \\
\hline Aged 20-24 & .534 & $\ldots$ & 390,617 \\
\hline Female & .504 & $\ldots$ & 390,617 \\
\hline Black & .149 & $\ldots$ & 390,617 \\
\hline Hispanic & .153 & $\ldots$ & 390,617 \\
\hline High school or less, $20-24$ & .445 & $\ldots$ & 200,116 \\
\hline High school dropout, 20-24 & .136 & $\ldots$ & 200,116 \\
\hline State unemployment rate & .050 & .011 & 390,617 \\
\hline \multicolumn{4}{|l|}{$\begin{array}{l}\text { Proportion of population aged } 16 \\
\text { and over age: }\end{array}$} \\
\hline $16-19$ & .079 & .015 & 390,617 \\
\hline $16-24$ & .172 & .024 & 390,617 \\
\hline $20-24$ & .093 & .018 & 390,617 \\
\hline \multicolumn{4}{|l|}{ Labor market outcomes } \\
\hline Wages, 16-19 & 6.74 & 2.86 & 59,346 \\
\hline Wages, 16-24 & 8.60 & 5.16 & 158,470 \\
\hline Wages, 20-24 & 9.61 & 5.81 & 99,124 \\
\hline Employed, 16-19 & .397 & $\ldots$ & 190,501 \\
\hline Employed, 16-24 & .550 & $\ldots$ & 390,617 \\
\hline Employed, 20-24 & .684 & $\ldots$ & 200,116 \\
\hline Earnings, 16-19 & 55.95 & 110.69 & 171,934 \\
\hline Earnings, 16-24 & 135.04 & 212.60 & 332,637 \\
\hline Earnings, 20-24 & 213.13 & 255.84 & 160,703 \\
\hline Earnings, 16-19, earnings $>0$ & 169.34 & 133.73 & 59,106 \\
\hline Earnings, $16-24$, earnings $>0$ & 288.85 & 228.59 & 158,152 \\
\hline Earnings, 20-24, earnings $>0$ & 353.51 & 242.78 & 99,046 \\
\hline \multicolumn{4}{|l|}{ Policy variables } \\
\hline Minimum wage & 5.37 & .55 & 390,617 \\
\hline $\begin{array}{l}\text { Minimum wage, states above } \\
\text { federal }\end{array}$ & 6.31 & .53 & 86,559 \\
\hline State EITC & .041 & .085 & 390,617 \\
\hline State EITC, states with EITC & .164 & .095 & 104,135 \\
\hline $\begin{array}{l}\text { State EITC refundable, states } \\
\text { with EITC }\end{array}$ & .8184 & $\ldots$ & 104,135 \\
\hline $\begin{array}{l}\text { State EITC fully refundable, } \\
\text { states with EITC }\end{array}$ & .8180 & $\ldots$ & 104,135 \\
\hline
\end{tabular}

Standard deviations are reported for continuous variables. Earnings are weekly, and are computed as wages multiplied by hours, set to zero for those not working. Estimates are weighted. Observations using allocated data to construct wages, employment, or earnings are deleted. Individual and state statistics are shown for the full employment sample, which drops the fewest observations owing to allocated data. The unemployment rates are not seasonally adjusted figures from local area unemployment statistics (http://data.bls.gov/cgi-bin/dsrv, viewed April 5, 2006). 
Table 2: Estimated Effects of Log Minimum Wages on Employment, 1997-2005

\begin{tabular}{|c|c|c|c|c|c|}
\hline \multirow{2}{*}{$\begin{array}{l}\text { Sample } \\
\text { Ages }\end{array}$} & \multicolumn{3}{|c|}{ All } & \multirow{2}{*}{$\begin{array}{c}\begin{array}{c}\text { High } \\
\text { school } \\
\text { or less }\end{array} \\
20-24 \\
\end{array}$} & \multirow{2}{*}{$\begin{array}{c}\begin{array}{c}\text { High } \\
\text { school } \\
\text { dropout }\end{array} \\
20-24 \\
\end{array}$} \\
\hline & $16-19$ & $16-24$ & $20-24$ & & \\
\hline \multicolumn{6}{|l|}{ Specification 1} \\
\hline Log minimum wage & $-.054^{*}$ & -.019 & .041 & .092 & .122 \\
\hline \multicolumn{6}{|l|}{$\begin{array}{l}\text { Specification 2: add state-specific } \\
\text { linear time trends }\end{array}$} \\
\hline Log minimum wage & -.070 & -.025 & .030 & .016 & -.126 \\
\hline \multicolumn{6}{|l|}{ Specification 3} \\
\hline Log minimum wage, lagged 1 year & -.023 & -.014 & .012 & -.080 & -.194 \\
\hline \multicolumn{6}{|l|}{ Specification 4} \\
\hline Log minimum wage & $-.073^{*}$ & -.024 & .031 & .041 & -.091 \\
\hline Log minimum wage, lagged 1 year & .010 & -.003 & -.003 & -.098 & -.152 \\
\hline Sum & -.063 & -.027 & .028 & -.057 & -.243 \\
\hline Employment elasticity & -.158 & -.049 & .041 & -.088 & -.455 \\
\hline $\mathrm{N}$ & 190,501 & 390,617 & 200,116 & 87,915 & 25,887 \\
\hline
\end{tabular}

Statistical significance is indicated by * (10-percent significance level), ** (five percent) and *** (one percent). Standard errors are clustered on state. All specifications include controls for the share of the population in the group studied, the statewide unemployment rate, education (16 categories), black, Hispanic, marital status (7 CPS categories), state, and calendar year and month. Specifications 2-4 add state-specific trends. For the employment elasticity, the calculation is based on the summed effect, except in cases where either the contemporaneous or lagged effect was significant when included in isolation, but the summed effect was not, or when the contemporaneous or lagged effect alone was more strongly significant than the summed effect (based on the number of asterisks). In these cases, the calculation is based on the significant contemporaneous or lagged effect. Statistical significance of the elasticity reported corresponds to that of the coefficient estimate or sum of estimates from which it is calculated. 
Table 3: Estimated Effects of Log Minimum Wages on Employment, Disaggregated by Race/Ethnicity

\begin{tabular}{|c|c|c|c|c|c|c|c|c|c|c|c|c|}
\hline & \multicolumn{3}{|c|}{ Non-black, non-Hispanic } & \multicolumn{3}{|c|}{ Black or Hispanic } & \multicolumn{3}{|c|}{ Black } & \multicolumn{3}{|c|}{ Hispanic } \\
\hline Ages & $16-19$ & $16-24$ & $20-24$ & $16-19$ & $16-24$ & $20-24$ & $16-19$ & $16-24$ & $20-24$ & $16-19$ & $16-24$ & $20-24$ \\
\hline Specification 1 & & & & & & & & & & & & \\
\hline Log minimum wage & $-.081^{* * *}$ & -.023 & .034 & .010 & -.002 & .065 & .066 & .127 & $.214^{* *}$ & -.066 & $-.090^{* *}$ & -.005 \\
\hline $\begin{array}{l}\text { Specification 2: add state-specific } \\
\text { linear time trends }\end{array}$ & & & & & & & & & & & & \\
\hline Log minimum wage & -.071 & -.022 & .017 & -.067 & -.022 & .066 & -.115 & .043 & $.203^{* *}$ & -.049 & -.094 & -.075 \\
\hline Specification 3 & & & & & & & & & & & & \\
\hline Log minimum wage, lagged 1 year & .029 & .031 & .049 & $-.171^{*}$ & $-.185^{* *}$ & -.194 & -.155 & -.148 & -.175 & -.127 & $-.249^{* * *}$ & $-.275^{*}$ \\
\hline Specification 4 & & & & & & & & & & & & \\
\hline Log minimum wage & -.088 & -.034 & .005 & -.035 & .020 & .122 & -.093 & .080 & $.264^{* * *}$ & -.024 & -.043 & -.014 \\
\hline Log minimum wage, lagged 1 year & .067 & .046 & .047 & -.153 & $-.196^{* *}$ & $-.260^{* *}$ & -.107 & -.191 & $-.322^{*}$ & -.114 & $-.226^{* *}$ & $-.268^{* *}$ \\
\hline Sum & -.021 & .012 & .052 & $-.188^{* *}$ & $-.176^{* *}$ & -.138 & -.201 & -.110 & -.056 & -.138 & $-.269^{* *}$ & -.282 \\
\hline Employment elasticity & -.048 & .020 & .072 & $-.664^{* *}$ & $-.385^{* *}$ & -.226 & -.836 & -.275 & -.104 & -.426 & $-.491^{* * *}$ & $-.417^{*}$ \\
\hline $\mathrm{N}$ & 143,215 & 292,959 & 149,744 & 47,286 & 97,658 & 50,372 & 23,677 & 46,367 & 22,690 & 24,284 & 52,574 & 28,290 \\
\hline
\end{tabular}

See notes to Table 2 . 
Table 4: Estimated Effects of Log Minimum Wages on Employment, Disaggregated by Sex

\begin{tabular}{|c|c|c|c|c|c|c|c|c|c|c|c|}
\hline \multirow{2}{*}{\begin{tabular}{|l|} 
\\
Ages \\
\end{tabular}} & \multicolumn{3}{|c|}{ All } & \multicolumn{3}{|c|}{ Non-black, non-Hispanic } & \multicolumn{3}{|c|}{ Black or Hispanic } & \multirow{2}{*}{$\begin{array}{c}\begin{array}{c}\text { All, high } \\
\text { school or } \\
\text { less }\end{array} \\
20-24 \\
\end{array}$} & \multirow{2}{*}{$\begin{array}{c}\begin{array}{c}\text { All, high } \\
\text { school } \\
\text { dropout }\end{array} \\
20-24 \\
\end{array}$} \\
\hline & $16-19$ & $16-24$ & $20-24$ & $16-19$ & $16-24$ & $20-24$ & $16-19$ & $16-24$ & $20-24$ & & \\
\hline \multicolumn{12}{|l|}{ Males } \\
\hline \multicolumn{12}{|l|}{ Specification 1} \\
\hline Log minimum wage & $-.070^{* *}$ & $-.079^{* * *}$ & -.034 & $-.078^{*}$ & $-.070^{* *}$ & -.034 & -.075 & $-.097^{* *}$ & -.015 & -.034 & -.042 \\
\hline \multicolumn{12}{|l|}{$\begin{array}{l}\text { Specification 2: add state-specific } \\
\text { linear time trends }\end{array}$} \\
\hline Log minimum wage & -.066 & -.067 & -.021 & -.052 & -.051 & -.010 & -.108 & -.095 & -.021 & -.048 & -.129 \\
\hline \multicolumn{12}{|l|}{ Specification 3} \\
\hline Log minimum wage, lagged 1 year & -.124 & -.103 & -.063 & -.087 & -.051 & .015 & -.215 & $-.290^{* * *}$ & $-.370^{* *}$ & -.195 & .016 \\
\hline \multicolumn{12}{|l|}{ Specification 4} \\
\hline Log minimum wage & -.041 & -.047 & -.006 & -.033 & -.043 & -.015 & -.069 & -.035 & .068 & .001 & -.149 \\
\hline Log minimum wage, lagged 1 year & -.106 & -.081 & -.060 & -.073 & -.032 & .022 & -.178 & $-.271^{* * *}$ & $-.407^{* * *}$ & -.195 & .086 \\
\hline Sum & -.146 & -.129 & -.066 & -.106 & -.074 & .007 & -.247 & $-.306^{* * *}$ & $-.339^{*}$ & -.194 & -.063 \\
\hline Employment elasticity & -.376 & -.228 & -.092 & -.246 & -.124 & .009 & -.855 & $-.627^{* * *}$ & $-.552^{* *}$ & -.264 & -.095 \\
\hline $\mathrm{N}$ & 95,605 & 191,141 & 95,536 & 71,752 & 144,099 & 72,347 & 23,853 & 47,042 & 23,189 & 45,449 & 13,504 \\
\hline \multicolumn{12}{|l|}{ Females } \\
\hline \multicolumn{12}{|l|}{ Specification 1} \\
\hline Log minimum wage & -.040 & .023 & .086 & $-.088^{* *}$ & .009 & .083 & .082 & .065 & .103 & $.171^{* *}$ & .170 \\
\hline \multicolumn{12}{|l|}{$\begin{array}{l}\text { Specification 2: add state-specific } \\
\text { linear time trends }\end{array}$} \\
\hline Log minimum wage & -.075 & .002 & .055 & -.099 & -.012 & .031 & -.012 & .035 & .113 & .039 & -.243 \\
\hline \multicolumn{12}{|l|}{ Specification 3} \\
\hline Log minimum wage, lagged 1 year & .058 & .059 & .060 & .124 & .096 & .064 & -.164 & -.100 & -.028 & -.006 & $-.522^{* *}$ \\
\hline \multicolumn{12}{|l|}{ Specification 4} \\
\hline Log minimum wage & -.100 & -.014 & .046 & $-.148^{*}$ & -.041 & .016 & .025 & .063 & .134 & .046 & -.142 \\
\hline Log minimum wage, lagged 1 year & .102 & .065 & .039 & $.188^{*}$ & .114 & .057 & -.177 & -.132 & -.099 & -.027 & -.460 \\
\hline Sum & .002 & .051 & .085 & .040 & .073 & .072 & -.152 & -.069 & .035 & .019 & $-.601^{*}$ \\
\hline Employment elasticity & .006 & .095 & .131 & .087 & .124 & .105 & -.551 & -.162 & .064 & .034 & $-.798^{* *}$ \\
\hline $\mathrm{N}$ & 94,986 & 199,476 & 104,580 & 71,463 & 148,860 & 77,397 & 23,433 & 50,616 & 27,183 & 42,466 & 12,383 \\
\hline
\end{tabular}

See notes to Table 2 . 
Table 5: Summary of Wage and Employment Results

\begin{tabular}{|c|c|c|}
\hline & Employment elasticity & Wage elasticity \\
\hline \multicolumn{3}{|l|}{ Males and females combined } \\
\hline 16-19, all & -.158 & $.254^{* * *}$ \\
\hline 16-24, all & -.049 & .095 \\
\hline 20-24, all & .041 & .052 \\
\hline High school or less, 20-24 & -.088 & $.258^{* * *}$ \\
\hline High school dropout, 20-24 & -.455 & $.389^{* * *}$ \\
\hline 16-19, non-black, non-Hispanic & -.048 & $.304^{* * *}$ \\
\hline 16-24, non-black, non-Hispanic & .020 & .103 \\
\hline 20-24, non-black, non-Hispanic & .072 & .012 \\
\hline 16-19, black or Hispanic & $-.664^{* *}$ & -.093 \\
\hline 16-24, black or Hispanic & $-.385^{* *}$ & .044 \\
\hline 20-24, black or Hispanic & -.226 & .174 \\
\hline 16-19, black & -.836 & .114 \\
\hline 16-24, black & -.275 & .138 \\
\hline 20-24, black & -.104 & .179 \\
\hline 16-19, Hispanic & -.426 & -.133 \\
\hline 16-24, Hispanic & $-.491^{* * *}$ & -.042 \\
\hline 20-24, Hispanic & $-.417^{*}$ & .166 \\
\hline \multicolumn{3}{|l|}{ Males } \\
\hline 16-19, all & -.376 & $.224^{* * *}$ \\
\hline 16-24, all & -.228 & $.128^{* *}$ \\
\hline 20-24, all & -.092 & .098 \\
\hline 16-19, non-black, non-Hispanic & -.246 & $.386^{* * *}$ \\
\hline 16-24, non-black, non-Hispanic & -.124 & $.164^{* *}$ \\
\hline 20-24, non-black, non-Hispanic & .009 & .086 \\
\hline 16-19, black or Hispanic & -.855 & $-.369^{* *}$ \\
\hline 16-24, black or Hispanic & $-.627^{* * *}$ & -.124 \\
\hline 20-24, black or Hispanic & $-.552^{* *}$ & .043 \\
\hline High school or less, 20-24 & -.264 & $.233^{* *}$ \\
\hline High school dropout, 20-24 & -.095 & $.438^{* *}$ \\
\hline \multicolumn{3}{|l|}{ Females } \\
\hline 16-19, all & .006 & $.286^{* * *}$ \\
\hline 16-24, all & .095 & .064 \\
\hline $20-24$, all & .131 & -.032 \\
\hline 16-19, non-black, non-Hispanic & .087 & $.250^{* *}$ \\
\hline 16-24, non-black, non-Hispanic & .124 & .020 \\
\hline 20-24, non-black, non-Hispanic & .105 & $-.143^{* *}$ \\
\hline 16-19, black or Hispanic & -.551 & .207 \\
\hline 16-24, black or Hispanic & -.162 & .233 \\
\hline 20-24, black or Hispanic & .064 & $.289^{*}$ \\
\hline High school or less, 20-24 & .034 & $.247^{* *}$ \\
\hline High school dropout, 20-24 & $-.798^{* *}$ & $.434^{* * *}$ \\
\hline
\end{tabular}

Results in first column are from Tables 2-4. Results in second column are from wage equations paralleling the employment specifications in Tables 2-4; see notes to Table 2. Observations with nominal wage below $\$ 1$ are dropped. The specification for computing the wage elasticities was chosen in the same way as for the employment elasticities in Tables 2-4. 
Table 6: Estimated Effects of Minimum Wages, EITC, and Welfare Reforms on Female Employment

\begin{tabular}{|c|c|c|c|c|c|c|c|c|c|c|c|}
\hline \multirow[b]{2}{*}{ Ages } & \multicolumn{3}{|c|}{ All } & \multicolumn{3}{|c|}{ Non-black, non-Hispanic } & \multicolumn{3}{|c|}{ Black or Hispanic } & \multirow{2}{*}{$\begin{array}{c}\begin{array}{c}\text { All, high } \\
\text { school } \\
\text { or less }\end{array} \\
20-24 \\
\end{array}$} & \multirow{2}{*}{$\begin{array}{c}\text { All, high } \\
\text { school } \\
\text { dropout }\end{array}$} \\
\hline & $16-19$ & $16-24$ & $20-24$ & $16-19$ & $16-24$ & $20-24$ & $16-19$ & $16-24$ & $20-24$ & & \\
\hline $\begin{array}{l}\text { Baseline minimum wage elasticity } \\
\text { (Table 4) }\end{array}$ & .006 & .095 & .131 & .087 & .124 & .105 & -.551 & -.162 & .064 & .034 & $-.798^{* *}$ \\
\hline \multicolumn{12}{|l|}{ Specification 1} \\
\hline Log minimum wage & -.106 & -.003 & .070 & $-.153^{*}$ & -.034 & .034 & .015 & .086 & .182 & .073 & -.095 \\
\hline Log minimum wage, lagged 1 year & .105 & .059 & .026 & $.191^{*}$ & .110 & .046 & -.173 & -.143 & -.122 & -.040 & $-.486^{*}$ \\
\hline State EITC (percentage supplement) & .003 & $.182^{* * *}$ & $.302^{* * *}$ & .035 & $.170^{* * *}$ & $.276^{* * *}$ & -.096 & $.224^{* * *}$ & $.397^{* * *}$ & $.446^{* * *}$ & .397 \\
\hline Welfare time limits imposed & .012 & -.003 & -.015 & .014 & .001 & -.009 & 007 & -.013 & -.032 & -.007 & -.031 \\
\hline Work requirements & .026 & .016 & .008 & .023 & .001 & -.017 & .027 & .057 & .093 & .010 & .127 \\
\hline $\begin{array}{l}\text { Joint significance of welfare } \\
\text { variables, p-value }\end{array}$ & .189 & .693 & .579 & .131 & .986 & .665 & .788 & .506 & .329 & .956 & .485 \\
\hline Minimum wage elasticity & -.002 & .104 & .148 & .083 & .130 & .116 & -.572 & -.135 & .108 & .058 & -1.503 \\
\hline \multicolumn{12}{|l|}{ Specification 2} \\
\hline $\begin{array}{l}\text { Average of log minimum wage and } \\
\text { log minimum wage lagged } 1 \text { year }\end{array}$ & -.042 & .033 & .086 & -.022 & .044 & .065 & -.088 & -.006 & .111 & .035 & -.520 \\
\hline Minimum wage elasticity & -.104 & .062 & .133 & -.048 & .075 & .094 & -.317 & -.015 & .200 & .062 & -1.345 \\
\hline \multicolumn{12}{|l|}{ Specification 3} \\
\hline $\begin{array}{l}\text { Average of log minimum wage and } \\
\text { log minimum wage lagged } 1 \text { year }\end{array}$ & .030 & .069 & .085 & .014 & .075 & .088 & .046 & .031 & .060 & .076 & -.363 \\
\hline State EITC (percentage supplement) & -.087 & $.137^{* *}$ & $.310^{* * *}$ & .018 & $.140^{*}$ & $.243^{* * *}$ & $-.367^{*}$ & $.160^{*}$ & $.533^{* * *}$ & $.394^{* * *}$ & .119 \\
\hline Log minimum wage variable $\mathrm{x}$ EITC & $-1.127^{* *}$ & -.451 & .213 & -.514 & -.388 & -.216 & $-2.411^{* *}$ & -.441 & 1.314 & -.414 & -2.367 \\
\hline $\begin{array}{l}\text { Minimum wage elasticity, no state } \\
\text { EITC }\end{array}$ & .074 & .129 & .131 & .031 & .129 & .127 & .166 & .072 & .109 & .135 & -.941 \\
\hline $\begin{array}{l}\text { Minimum wage elasticity, } 10 \% \text { state } \\
\text { EITC supplement }\end{array}$ & -.205 & .045 & .164 & -.081 & .062 & .096 & -.706 & -.032 & .345 & .062 & $-1.553^{*}$ \\
\hline $\begin{array}{l}\text { Minimum wage elasticity, } 25 \% \text { state } \\
\text { EITC supplement }\end{array}$ & $-.623^{*}$ & -.081 & .213 & -.249 & -.038 & .049 & $-2.015^{* *}$ & -.187 & $.700^{* *}$ & -.048 & $-2.471^{* * *}$ \\
\hline $\mathrm{N}$ & 94,896 & 199,476 & 104,580 & 71,463 & 148,860 & 77,397 & 23,433 & 50,616 & 27,183 & 42,466 & 12,383 \\
\hline
\end{tabular}

See notes to Table 2. Specifications include the same control variables as specification 4 in Tables 2-4. In the interactive specifications, the interaction is between the minimum wage variable minus its mean and the EITC. This way, the non-interacted EITC coefficients measure the effects of the EITC evaluated at the mean minimum wage; the transformation has no effect on the interactive coefficients. 
Table 7: Estimated Effects of Minimum Wages and the EITC on Female Wages and Earnings

\begin{tabular}{|c|c|c|c|c|c|c|c|c|c|c|c|}
\hline \multirow[b]{2}{*}{ Ages } & \multicolumn{3}{|c|}{ All } & \multicolumn{3}{|c|}{ Non-black, non-Hispanic } & \multicolumn{3}{|c|}{ Black or Hispanic } & \multirow{2}{*}{$\begin{array}{c}\text { All, high } \\
\text { school } \\
\text { or less } \\
20-24\end{array}$} & \multirow{2}{*}{ 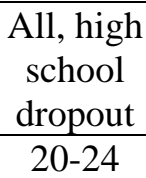 } \\
\hline & $16-19$ & $16-24$ & $20-24$ & $16-19$ & $16-24$ & $20-24$ & $16-19$ & $16-24$ & $20-24$ & & \\
\hline \multicolumn{12}{|l|}{ Female Wages } \\
\hline Log minimum wage & $.136^{*}$ & .109 & .059 & .157 & .128 & .070 & -.046 & .053 & .031 & .110 & $.508^{* * *}$ \\
\hline Log minimum wage, lagged 1 year & $.152^{*}$ & -.046 & -.095 & .094 & $-.107^{*}$ & $-.172^{* *}$ & $.251^{*}$ & .175 & $.271^{*}$ & .136 & -.273 \\
\hline State EITC (percentage supplement) & .096 & -.037 & -.133 & .085 & .048 & -.004 & .125 & $-.250^{* *}$ & $-.408^{* *}$ & -.039 & .245 \\
\hline Minimum wage elasticity & $.287^{* * *}$ & .063 & -.035 & $.252^{* *}$ & .021 & -.103 & .206 & .228 & .301 & $.247^{*}$ & .235 \\
\hline $\mathrm{N}$ & 30,574 & 80,386 & 50,262 & 25,774 & 65,505 & 39,761 & 4,830 & 15,331 & 10,501 & 17,943 & 3,668 \\
\hline \multicolumn{12}{|l|}{ Female Earnings } \\
\hline \multicolumn{12}{|l|}{ Specification 1} \\
\hline $\begin{array}{l}\text { Average of log minimum wage and } \\
\text { log minimum wage lagged } 1 \text { year }\end{array}$ & 7.34 & -10.10 & -28.44 & 10.85 & -31.66 & -82.20 & -7.90 & 39.09 & $111.12^{*}$ & 29.72 & -90.55 \\
\hline State EITC (percentage supplement) & $24.44^{*}$ & $44.55^{* * *}$ & 47.11 & 31.09 & $48.67^{* * *}$ & 53.83 & 3.27 & 38.43 & 39.77 & $110.15^{*}$ & $141.55^{*}$ \\
\hline Minimum wage elasticity & .141 & -.086 & -.158 & .185 & -.242 & -.416 & -.212 & .437 & .797 & .213 & -1.167 \\
\hline \multicolumn{12}{|l|}{ Specification 2} \\
\hline $\begin{array}{l}\text { Average of log minimum wage and } \\
\text { log minimum wage lagged } 1 \text { year }\end{array}$ & 19.61 & -11.55 & -40.94 & 21.98 & -28.43 & -83.64 & 5.26 & 28.54 & 79.45 & 34.83 & -48.87 \\
\hline State EITC (percentage supplement) & 4.19 & $47.02^{* *}$ & $68.92^{*}$ & 14.23 & 43.73 & 56.05 & -22.98 & $61.00^{* *}$ & $111.28^{* *}$ & 100.63 & 66.71 \\
\hline Log minimum wage variable $\mathrm{x}$ EITC & $-198.25^{* *}$ & 23.97 & 210.48 & -173.46 & -51.47 & 23.51 & $-231.48^{*}$ & 188.76 & $577.11^{* *}$ & -95.49 & $-744.64^{*}$ \\
\hline $\begin{array}{l}\text { Minimum wage elasticity, no state } \\
\text { EITC }\end{array}$ & .378 & -.098 & -.227 & .376 & -.218 & -.423 & .141 & .319 & .570 & .249 & -.630 \\
\hline $\begin{array}{l}\text { Minimum wage elasticity, } 10 \% \text { state } \\
\text { EITC supplement }\end{array}$ & -.004 & -.078 & -.111 & .079 & -.257 & -.411 & -.479 & .531 & $.984^{*}$ & .181 & $-1.589^{*}$ \\
\hline $\begin{array}{l}\text { Minimum wage elasticity, 25\% state } \\
\text { EITC supplement }\end{array}$ & -.577 & -.047 & .065 & -.366 & -.316 & -.393 & $-1.409^{*}$ & $.847^{*}$ & $1.606^{* *}$ & .078 & $-3.028^{* * *}$ \\
\hline $\mathrm{N}$ & 85,698 & 171,741 & 86,043 & 63,883 & 127,254 & 63,371 & 21,815 & 44,487 & 22,672 & 36,040 & 11,214 \\
\hline
\end{tabular}

See notes to Tables 2 and 6 . Earnings are the product of wages and hours, and are set to zero if hours are zero. 
Table 8: Estimated Effects of Minimum Wages and the EITC on Male Wages and Earnings

\begin{tabular}{|c|c|c|c|c|c|c|c|c|c|c|c|}
\hline \multirow[b]{2}{*}{ Ages } & \multicolumn{3}{|c|}{ All } & \multicolumn{3}{|c|}{ Non-black, non-Hispanic } & \multicolumn{3}{|c|}{ Black or Hispanic } & \multirow{2}{*}{$\begin{array}{c}\begin{array}{c}\text { All, high } \\
\text { school or } \\
\text { less }\end{array} \\
20-24 \\
\end{array}$} & \multirow{2}{*}{ 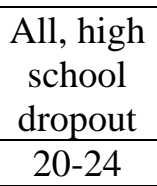 } \\
\hline & $16-19$ & $16-24$ & $20-24$ & $16-19$ & $16-24$ & $20-24$ & $16-19$ & $16-24$ & $20-24$ & & \\
\hline \multicolumn{12}{|l|}{ Male Wages } \\
\hline $\begin{array}{l}\text { Average of log minimum wage and } \\
\text { log minimum wage lagged } 1 \text { year }\end{array}$ & $.215^{* * *}$ & .115 & .106 & $.395^{* * *}$ & .145 & .036 & $-.523^{* *}$ & .019 & .247 & $.268^{* *}$ & .603 \\
\hline State EITC (percentage supplement) & .180 & .025 & -.088 & .153 & .129 & .084 & .267 & $-.546^{* *}$ & $-.898^{* * *}$ & .233 & -.052 \\
\hline Log minimum wage variable $\mathrm{x}$ EITC & -.099 & -.505 & -.694 & -.148 & .200 & .478 & .029 & $-3.823^{*}$ & $-5.315^{* *}$ & -.170 & -1.697 \\
\hline $\begin{array}{l}\text { Minimum wage elasticity, no state } \\
\text { EITC }\end{array}$ & $.215^{* * *}$ & .115 & .106 & $.395^{* * *}$ & .145 & .036 & -.523 & .019 & .247 & $.268^{* *}$ & $.520^{* *}$ \\
\hline $\begin{array}{l}\text { Minimum wage elasticity, } 10 \% \text { state } \\
\text { EITC supplement }\end{array}$ & $.205^{* *}$ & .065 & .037 & $.380^{* * *}$ & .165 & .083 & $-.520^{*}$ & -.363 & -.284 & $.251^{* *}$ & $.434^{* *}$ \\
\hline $\begin{array}{l}\text { Minimum wage elasticity, } 25 \% \text { state } \\
\text { EITC supplement }\end{array}$ & .190 & -.011 & -.067 & .358 & .195 & .155 & -.516 & $-.937^{*}$ & $-1.081^{*}$ & .226 & .179 \\
\hline $\mathrm{N}$ & 28,772 & 77,634 & 48,862 & 23,738 & 61,836 & 38,098 & 5,034 & 15,798 & 10,764 & 23,703 & 6,537 \\
\hline \multicolumn{12}{|l|}{ Male Earnings } \\
\hline \multicolumn{12}{|l|}{ Specification 1} \\
\hline $\begin{array}{l}\text { Average of log minimum wage and } \\
\text { log minimum wage lagged } 1 \text { year }\end{array}$ & -9.87 & -22.61 & -5.06 & 21.88 & 20.31 & 48.96 & $-89.02^{* * *}$ & $-123.77^{*}$ & -122.77 & 1.51 & -20.32 \\
\hline State EITC (percentage supplement) & -3.92 & 38.77 & 87.71 & -12.06 & 84.58 & 173.86 & 18.20 & -58.13 & $-128.52^{* *}$ & 139.81 & 60.98 \\
\hline Minimum wage elasticity & -.165 & -.148 & -.020 & .330 & .122 & .182 & -1.964 & -1.023 & -.607 & .006 & -.102 \\
\hline \multicolumn{12}{|l|}{ Specification 2} \\
\hline $\begin{array}{l}\text { Average of log minimum wage and } \\
\text { log minimum wage lagged } 1 \text { year }\end{array}$ & -19.69 & -30.63 & -4.60 & 12.77 & -1.68 & 17.82 & $-97.98^{* * *}$ & -91.12 & -39.05 & -22.96 & -36.75 \\
\hline State EITC (percentage supplement) & 12.95 & 52.22 & 86.98 & 1.02 & 116.17 & $218.56^{*}$ & 39.85 & -134.38 & $-311.07^{* * *}$ & 183.81 & 86.56 \\
\hline Log minimum wage variable $\mathrm{x}$ EITC & 155.94 & 129.21 & -7.38 & 138.24 & 337.06 & 481.77 & 158.64 & -594.58 & $-1575.24^{* *}$ & 425.58 & 282.43 \\
\hline $\begin{array}{l}\text { Minimum wage elasticity, no state } \\
\text { EITC }\end{array}$ & -.329 & -.200 & -.018 & .193 & -.010 & .066 & $-2.161^{* * *}$ & -.753 & -.193 & -.091 & -.185 \\
\hline $\begin{array}{l}\text { Minimum wage elasticity, } 10 \% \text { state } \\
\text { EITC supplement }\end{array}$ & -.068 & -.116 & -.021 & .401 & .192 & .245 & $-1.811^{* *}$ & $-1.245^{* *}$ & -.971 & .078 & -.043 \\
\hline $\begin{array}{l}\text { Minimum wage elasticity, 25\% state } \\
\text { EITC supplement }\end{array}$ & .322 & .011 & -.026 & .714 & .496 & .514 & -1.286 & $-1.983^{* *}$ & $-2.139^{* *}$ & .331 & .170 \\
\hline $\mathrm{N}$ & 86,236 & 160,896 & 74,460 & 64,257 & 120,884 & 56,627 & 21,979 & 40,012 & 18,033 & 35,313 & 10,971 \\
\hline
\end{tabular}

See notes to Tables 2 and 6. 
Appendix Table A1: Estimates of Employment Effects Omitting State-Specific Trends

\begin{tabular}{|c|c|}
\hline & $\begin{array}{c}\text { Employment elasticity } \\
\text { without trends }\end{array}$ \\
\hline \multicolumn{2}{|l|}{ Males and females combined } \\
\hline 16-19, all & -.095 \\
\hline 16-24, all & -.023 \\
\hline 20-24, all & .059 \\
\hline High school or less, $20-24$ & $.090^{* * *}$ \\
\hline High school dropout, 20-24 & .137 \\
\hline 16-19, non-black, non-Hispanic & $-.150^{* *}$ \\
\hline 16-24, non-black, non-Hispanic & -.025 \\
\hline 20-24, non-black, non-Hispanic & .057 \\
\hline 16-19, black or Hispanic & .090 \\
\hline 16-24, black or Hispanic & -.009 \\
\hline 20-24, black or Hispanic & .079 \\
\hline 16-19, black & .524 \\
\hline 16-24, black & $.353^{*}$ \\
\hline 20-24, black & $.349^{*}$ \\
\hline 16-19, Hispanic & -.179 \\
\hline 16-24, Hispanic & $-.175^{*}$ \\
\hline 20-24, Hispanic & -.007 \\
\hline \multicolumn{2}{|l|}{ Males } \\
\hline 16-19, all & $-.174^{*}$ \\
\hline 16-24, all & $-.085^{* *}$ \\
\hline $20-24$, all & -.049 \\
\hline 16-19, non-black, non-Hispanic & $-.189^{*}$ \\
\hline 16-24, non-black, non-Hispanic & $-.128^{* *}$ \\
\hline 20-24, non-black, non-Hispanic & -.058 \\
\hline 16-19, black or Hispanic & -.243 \\
\hline 16-24, black or Hispanic & $-.230^{* * *}$ \\
\hline 20-24, black or Hispanic & -.072 \\
\hline High school or less, 20-24 & -.085 \\
\hline High school dropout, 20-24 & -.020 \\
\hline \multicolumn{2}{|l|}{ Females } \\
\hline 16-19, all & -.029 \\
\hline 16-24, all & .074 \\
\hline 20-24, all & .149 \\
\hline 16-19, non-black, non-Hispanic & -.055 \\
\hline 16-24, non-black, non-Hispanic & .053 \\
\hline 20-24, non-black, non-Hispanic & .147 \\
\hline 16-19, black or Hispanic & $.361^{*}$ \\
\hline 16-24, black or Hispanic & $.160^{*}$ \\
\hline 20-24, black or Hispanic & .176 \\
\hline High school or less, $20-24$ & $.322^{* *}$ \\
\hline High school dropout, 20-24 & .382 \\
\hline
\end{tabular}

All elasticities are from specification 4 in Tables 2-4, with the exception of excluding the state-specific trends. 
Appendix Table A2: Estimates of Welfare Reform and EITC Effects Omitting State-Specific Trends

\begin{tabular}{|c|c|c|c|c|c|c|c|c|c|c|c|}
\hline \multirow[b]{2}{*}{ Ages } & \multicolumn{3}{|c|}{ All } & \multicolumn{3}{|c|}{ Non-black, non-Hispanic } & \multicolumn{3}{|c|}{ Black or Hispanic } & \multirow{2}{*}{$\begin{array}{c}\text { All, high } \\
\text { school } \\
\text { or less } \\
20-24\end{array}$} & \multirow{2}{*}{$\begin{array}{c}\text { All, high } \\
\text { school } \\
\text { dropout }\end{array}$} \\
\hline & 16-19 & $16-24$ & $20-24$ & $16-19$ & $16-24$ & $20-24$ & 16-19 & $16-24$ & $20-24$ & & \\
\hline \multicolumn{12}{|l|}{ Female Employment } \\
\hline $\begin{array}{l}\text { Average of log minimum wage and } \\
\text { log minimum wage lagged } 1 \text { year }\end{array}$ & -.005 & .050 & $.106^{*}$ & -.058 & .036 & .107 & $.106^{*}$ & $.087^{* *}$ & $.118^{* *}$ & $.198^{* * *}$ & .193 \\
\hline State EITC (percentage supplement) & .009 & $.109^{* * *}$ & $.179^{* * *}$ & .022 & .067 & .106 & -.008 & $.187^{* *}$ & $.297^{* * *}$ & $.372^{* * *}$ & $.713^{* * *}$ \\
\hline Log minimum wage variable $\mathrm{x}$ EITC & -.281 & -.141 & .075 & -.044 & -.086 & -.023 & -.473 & -.199 & .270 & .171 & -.081 \\
\hline $\begin{array}{l}\text { Minimum wage elasticity, no state } \\
\text { EITC }\end{array}$ & -.011 & .093 & $.163^{*}$ & -.125 & .061 & .155 & $.383^{*}$ & $.205^{* *}$ & $.212^{* *}$ & $.349^{* * *}$ & .498 \\
\hline $\begin{array}{l}\text { Minimum wage elasticity, } 10 \% \text { state } \\
\text { EITC supplement }\end{array}$ & -.081 & .067 & $.174^{*}$ & -.135 & .046 & .152 & .211 & .158 & $.261^{*}$ & $.379^{* * *}$ & .478 \\
\hline $\begin{array}{l}\text { Minimum wage elasticity, } 25 \% \text { state } \\
\text { EITC supplement }\end{array}$ & -.185 & .028 & .124 & -.150 & .024 & .147 & -.045 & .088 & .334 & $.425^{* *}$ & .446 \\
\hline \multicolumn{12}{|l|}{ Female Earnings } \\
\hline $\begin{array}{l}\text { Average of log minimum wage and } \\
\text { log minimum wage lagged } 1 \text { year }\end{array}$ & -1.71 & 4.95 & 18.36 & -11.03 & 2.77 & 17.19 & 19.03 & 15.99 & 34.44 & $55.48^{* * *}$ & 53.90 \\
\hline State EITC (percentage supplement) & 6.48 & 31.15 & 44.39 & 8.42 & 32.33 & 50.38 & .04 & 21.22 & 19.62 & $96.33^{* *}$ & $137.37^{*}$ \\
\hline Log minimum wage variable $\mathrm{x}$ EITC & -43.75 & 100.56 & 265.10 & -4.85 & 81.82 & 193.35 & -84.46 & 115.90 & 355.47 & $195.63^{*}$ & -232.70 \\
\hline $\begin{array}{l}\text { Minimum wage elasticity, no state } \\
\text { EITC }\end{array}$ & -.033 & .042 & .102 & -.188 & .021 & .087 & .509 & .179 & .247 & $.397^{* * *}$ & .694 \\
\hline $\begin{array}{l}\text { Minimum wage elasticity, } 10 \% \text { state } \\
\text { EITC supplement }\end{array}$ & -.117 & .127 & .249 & -.197 & .084 & .185 & .283 & .309 & $.502^{*}$ & $.537^{* * *}$ & .395 \\
\hline $\begin{array}{l}\text { Minimum wage elasticity, 25\% state } \\
\text { EITC supplement }\end{array}$ & -.243 & .255 & .470 & -.209 & .178 & .331 & -.056 & .503 & .885 & $.747^{* * *}$ & -.055 \\
\hline \multicolumn{12}{|l|}{ Male Earnings } \\
\hline $\begin{array}{l}\text { Average of log minimum wage and } \\
\text { log minimum wage lagged } 1 \text { year }\end{array}$ & 4.67 & 20.45 & $68.00^{* * *}$ & 8.31 & 29.33 & $71.13^{* *}$ & -7.96 & .98 & $68.54^{* *}$ & 61.10 & 68.86 \\
\hline State EITC (percentage supplement) & 17.69 & -11.05 & 22.75 & -22.06 & 6.67 & 54.93 & 8.13 & -34.36 & -45.91 & 66.39 & -61.25 \\
\hline Log minimum wage variable $\mathrm{x}$ EITC & 45.15 & -77.82 & -237.13 & 95.46 & -20.52 & -140.44 & -1.51 & -192.37 & -568.58 & -281.86 & -268.64 \\
\hline $\begin{array}{l}\text { Minimum wage elasticity, no state } \\
\text { EITC }\end{array}$ & .078 & .134 & $.273^{* * *}$ & .125 & .176 & .264 & -.175 & .008 & .339 & .242 & .346 \\
\hline $\begin{array}{l}\text { Minimum wage elasticity, } 10 \% \text { state } \\
\text { EITC supplement }\end{array}$ & .153 & .083 & .178 & .269 & .164 & .212 & -.179 & -.151 & .058 & .130 & .211 \\
\hline $\begin{array}{l}\text { Minimum wage elasticity, } 25 \% \text { state } \\
\text { EITC supplement }\end{array}$ & .266 & .007 & .035 & $.485^{*}$ & .145 & .134 & -.184 & -.390 & -.363 & -.037 & .009 \\
\hline
\end{tabular}

See notes to Tables 6 and 8. 